\title{
FROM THE DESK OF EDITOR in CHIEF
}

(J Banagladesh Coll Phys Surg 2015; 33: 116)

Dear Fellows

Every good thing comes to an end and opens the door for a better replacement. This is going to be my last letter to you as the Editor in Chief of our favorite journal. I and my team have tried our level best to uphold the high standards of the Journal of BCPS. During our tenure we have gotten rid of the back log and the issues are now up-to-date. Software has been developed to keep track of all the publication and the authors along with their submissions. A new website for the journal has been installed which now fully operational. The journal committee tried to ensure publication of quality original articles. Over the years there have been an increase in the number of subscribers and the journal now has a larger group of readers. Though we haven't been able to index the journal yet, we have taken necessary steps which will make it easier for the journal to be indexed in near future. I would like to thank the fellows and my editorial team for their relentless hard work and support and wish the best in life for all. Finally I would like to welcome the new Editor In Chief.

\author{
Prof. HAM Nazmul Ahasan \\ Editor In Chief \\ Journal of BCPS
}

